\title{
The Development of Winged Angels in Early Christian Art*
}

\author{
THERESE MARTIN ${ }^{\star \star}$
}

\begin{abstract}
RESUMEN: SUMMARY:
Las primeras representaciones de ángeles en el art paleocristianno fueron de un ser visualmente indiferenciado del hombre. Este estudio pretende explicar la aparición súbita de ángeles con alas, a fines del siglo $\mathrm{I}$, dentro de ese particular contexto históricoreligioso. El modelo de angel con alas fue Nike, una eleccion inusual si se tiene en cuenta que la Victoria fue concebida como mujer, mientras

The first representations of angels in Early Christian art showed a being visually indistinguishable from man. This study undertakes to explain the sudden apperarance of winged angels in the late fourth century within its religious and historical contexts The model for winged angels was Nike, an unusual choice given that Victory was conceived of as a female, while angels were decidedly male.
\end{abstract} que los ángeles eran indudablemente masculinos.

The angel is a being unseen yet easily describable; it has a certain ethereal beauty, flowing robes and, above all, majestic wings. In fact, the appearance of angels with wings is so familiar to us that it has become difficult to remember that this image has not always existed, that it was an invention that evolved during the first four centuries of Christianity. The appearance of angels had to be invented because canonical scripture provided but sparse descriptions. While the outward appearance of angels goes mostly undescribed, the nature and function of angels receives attention from the authors of the Bible. Angel, mal'akh in Hebrew and angelos in Greek, simply means messenger. Angels serve as intermediaries between God and people; they carry messages, now of

\footnotetext{
* This article had its origins in a 1997 seminar with Marina Warner, whom I wish to thank for her encouragement and astute critiques of early drafts.
}

** University of Arizona. 
imminent joy, now of doom and despair. In Exodus 23:20-23, God tells the Israelites what his angel will do for them and how they must treat the angel in response, but not how they are to recognize the angel: "I myself will send an angel before you to guard you as you go and to bring you to the place that I have prepared. Give him reverence and listen to all that he says. Offer him no defiance; he would not pardon such a fault, for my name is in him. If you listen carefully to his voice and do all that I say, I shall be enemy to your enemies, foe to your foes. My angel will go before you and lead you...»1 Despite the important roles played by angels in both the Old and New Testaments, their physical make-up is rarely described. Of the some 273 times that angels are mentioned in the Bible, not once are they said to have wings. 2 They are often simply referred to as men, although occasional allusions to their fantastic nature do occur. Psalm $104: 4$ praises God "who makes his angels into winds, his servants into flames of fire." This would become the standard basis for explaining the essence of angels. The visions of the prophet Daniel also helped to shape the church fathers' understanding of angels. «Still speaking, still at prayer, when the man Gabriel I had seen originally in a vision, flying in flight touched me at the hour of the evening sacrifice. He said to me, 'Daniel, you see me; I have come down to teach you how to understand.'" (Dan. $9: 21-22)$

Angels in the canonical books of the Bible interact with humanity at God's bidding. They have a majestic air about them, and they are referred to as both angels and men, sometimes even within a single story. We receive an indication of how remarkable the appearance of angels must be when two of them come to call on Lot in Genesis 19:1-13.

When the two angels reached Sodom in the evening, Lot was sitting at the gate. As soon as Lot saw them he rose to meet them and bowed to the ground. 'I beg you, my lords,' he said, 'please come down to your servant's house to stay the night and wash your feet.' ... They had not gone to bed when the house was surrounded by the men of the town, the men of Sodom both young and old, all the people without exception. Calling to Lot they said, 'Where are the men who came to you tonight? Send them out to us so that we may abuse them.' Lot came out to them at the door, and having closed the door behind him said, 'I beg you, my brothers, do no such wicked thing. Listen, I have two daughters who are virgins. I am ready to send them out to you, to treat as it pleases you. But as for the men, do nothing to them, for they have come under the shadow of my roof.'

1 Biblical quotes are from The Jerusalem Bible, New York, 1966.

2 Bernard N. Schneider cited the number of times angels appear in the Bible in his The World of Unseen Spirits: A Study Guide, Winona Lake, Indiana, 1975, 14. 
While the word angel calls to our minds an image of a robed figure with wings, the writer of Genesis does not explain how the angels appeared to Lot, only that he recognized them immediately and that their appearance led him to call them lords.

Angels of the Old Testament seem to have taken an active interest in humanity, at times too active for their own good. Genesis 6:1-6 tells briefly how some of the angels were lured to earth: "The sons of God, looking at the daughters of men, saw they were pleasing, so they married as many as they chose. ... The Nephilim [giants] were on the earth at that time (and even afterwards) when the sons of God resorted to the daughters of man, and had children by them. These are the heroes of days gone by, the famous men." Because of the women of earth, the angels chose to give up their heavenly position as sons of God. Despite the fact that wings are never explicitly referred to, angels were conceived of by the Biblical authors as occupying a place in the heavens. From above, they could look down on humanity and periodically make an appearance to mark a momentous occasion.

The earliest Christian writers, the Evangelists, give only limited descriptions of angels, emphasizing their shining whiteness. The terms angel and man are used interchangeably by the Gospel writers as they describe a certain presence at the tomb of Christ after he has risen. Here, once more, the appearance of the angels informs the reader that something far out of the ordinary has occurred.

"And all at once there was a violent earthquake, for the angel of the Lord, descending from heaven, came and rolled away the stone and sat on it. His face was like lightning, his robe white as snow." (Matt. 28:1-8)

"On entering the tomb they saw a young man in a white robe seated on the right-hand side and they were struck with amazement.» (Mark 16:5)

"As they stood there not knowing what to think, two men in brilliant clothes suddenly appeared at their side.» (Luke 24:4)

"Meanwhile Mary stayed outside near the tomb, weeping. Then, still weeping, she stooped to look inside, and saw two angels in white sitting where the body of Jesus had been, one at the head, the other at the feet." (John 20:11-12)

Angels appear throughout the New Testament, yet they never receive a portrayal more elaborated than in these tomb scenes. 
More detailed descriptions of the physical appearance of angels are provided by the Pseudepigrapha, early Jewish writings that were influential in the development of Christianity despite never gaining acceptance into the Biblical canon. The story of the angels who chose to leave heaven for more earthly pleasures is told at length in the Pseudepigraphal Book of Enoch (also called 1 Enoch, written c.200 BC to $100 \mathrm{AD}$ ). ${ }^{3}$ The Book of Enoch relates that angels married women, then taught them «charms and enchantments, and the cutting of roots." 41 Enoch 6-8: "And it came to pass when the children of men had multiplied that in those days were born unto them beautiful and comely daughters. And the angels, the children of the heaven, saw and lusted after them, and said to one another: 'Come, let us choose us wives from among the children of men and beget us children'." Unfortunately, as the story is told in I Enoch 8, the children of these unlawful unions between angels and women were giants and cannibals, so in order to protect humanity from their offspring the angels taught people "to make swords, and knives, and shields, and breastplates, and made known to them the metals [of the earth] and the art of working them, and bracelets, and ornaments, and the use of antimony, and the beautifying of the eyelids, and all kinds of costly stones, and all coloring tinctures." The angels taught humankind the arts of making weapons and of making beauty; thus, through the illicit interaction of women and angels came knowledge that would lead to death and deception.

Interaction between humanity and angels, when it is not at God's behest, leads to their downfall. As for what happens to the angels who chose to come to earth, Enoch reports in 19:1-2:

And Uriel [one of the good angels] said to me: Here shall stand the angels who have connected themselves with women, and their spirits assuming many different forms are defiling mankind and shall lead them astray into sacrificing to demons as gods, (here shall they stand) till the day of the great judgment in which they shall be judged till they are made an end of. And the women also of the angels who went astray shall become sirens.

The idea of union between women and angels is thus revealed as a source of anxiety. They who led angels astray are equated with sirens, the bird-women of mythology whose beautiful voices led men to their deaths. Interestingly, though the angels are not described as winged, the women who united with them are condemned to take a winged form.

3 See R.H. Charles, ed., The Apocrypha and Pseudepigrapha of the Old Testament, 2 vols., Oxtord, 1913.

4 For I Enoch, see Charles, 1913, 188-277. 
In the Book of Enoch, we find but a single early reference to a winged angel. "And I saw in those days how long cords [for measuring] were given to those angels, and they took to themselves wings and flew, and they went towards the north." (I Enoch 61:1) That the angels had to take "to themselves wings" in order to complete their assigned task of measuring Paradise would seem to indicate that the natural state of an angel was without wings. This is confirmed in the story of the birth of Noah, as told again by Enoch, his great-grandfather. Noah's mother gives birth to a son

the like of whom there is none, and his nature is not like man's nature, and the color of his body is whiter than snow and redder than the bloom of a rose, and the hair of his head is whiter than white wool, and his eyes are like the rays of the sun, and he opened his eyes and thereupon lighted up the whole house. And he arose in the hands of the midwife, and opened his mouth and blessed the Lord of heaven. And his father Lamech became afraid and fled to me, and did not believe that he was sprung from him, but that he was in the likeness of the angels of heaven. (I Enoch 106:10-12)

Brilliance, not wings, is thus the key identifying characteristic of angels in their earliest complete descriptions from both canonical and noncanonical sources.

The Second Book of Enoch or the Book of the Secrets of Enoch, another Pseudepigraphal text, was written some time during the first century $A D$, and it exercised its influence over both Jewish and Christian authors in the early centuries of our era. 5 This Enoch would seem to confirm the description of angels left by his earlier namesake. Enoch is carried up to heaven and there experiences many marvels.

And the Lord said to Michael [the archangel]: 'Go and take Enoch from out his earthly garments, and anoint him with my sweet ointment, and put him into the garments of My glory.' And Michael did thus, as the Lord told him. He anointed me, and dressed $m e$, and the appearance of that ointment is more than the great light, and his ointment is like sweet dew, and its smell mild, shining like the sun's ray, and I looked at myself, and was like one of his glorious ones. (II Enoch 22:8-10 A). ${ }^{6}$

5 For II Enoch, see Charles, 1913, 425-469. It «was referred to by Origen and probably by Clement of Alexandria, and used by Irenaeus, and a few phrases in the New Testament may be derived from it." (425).

6 This book comes down to us in two slightly different versions referred to as $A$ and $B$. In the second version Enoch reports: "And Michael took me out from my garments, and anointed me with sweet oil; and the appearance of that oil is better than great light, and its ointment like sweet dew, and its smell like myrrh, and shining like the rays of the sun. And I looked down looking at myself, and I was as one of the glorious ones, and there was no difference." (II Enoch 22:8-10 B) 
Enoch had become like the angels because of his glorious brilliance, not because he had been given wings.

But the Second Book of Enoch also provides vivid descriptions of angels with wings. This text, written during the formative years of the new Christian religion, is the only text of its time to provide descriptions of winged angels that has survived to our day.

1:4-5 (A) And there appeared to me two men, exceeding big, so that I never saw such on earth; their faces were shining like the sun, their eyes too were like a burning light, and from their lips was fire coming forth, with clothing and singing of various kinds in appearance purple, their wings were brighter than gold, their hands whiter than snow. ${ }^{7}$

In the passage above, wings are mentioned yet the key characteristic of the angel remains its brilliance. In other passages of the Second Book of Enoch, however, the angels' wings and flight are given more prominent notice.

$3: 1$ «lt came to pass, when Enoch had told his sons, that the angels took him on to their wings and bore him up on to the first heaven and placed him on the clouds."

4:1-2 "They brought before my face the elders and rulers of the stellar orders, and showed me two hundred angels, who rule the stars and their services to the heavens, and fly with their wings and come round all those who sail.»

During the first centuries of Christianity, a specifically Christian iconography began to develop that included visual representations of angels. 8 Borrowing from classical imagery and Jewish sources, a new Christian art was created to illustrate the most important lessons from the Bible. The oldest surviving images of angels are in the Catacombs of Rome; they date to the second half of the third century and the beginning of the fourth century. ${ }^{9}$ Because angels must take some form in order to be perceived by humans, they are often anthropomorphized. The earliest Christian angels are visually undifferentiated from men. Only a knowledge of the iconography allows the viewer to recognize that some of the figures

7 Version B, 1:4-5 "... and there appeared to me two very big men, such as 1 have never seen on earth-their faces shone like the sun, their eyes were like burning candles, out of their mouths was fire coming forth, their clothes and singing were varibus, and their arms like golden wings..."

8 Glen Peers' new study, Subtle Bodies: Representing Angels in Byzantium, Berkeley, 2001, appeared when this article was already in press.

9 For the Catacombs, see Johann Wilpert, Die Malereien der Katakomben Roms, 1903; Vincenzo FIOCCHI NICOLAI, Fabrizio BISCONTI, Danilo MAZZOLENI, La Catacombe Cristiane di Roma, Regensburg, 1998. 
that appear to be men are actually angels. Yet according to Psalm 104, angels are beings of fire and wind. How could the first Christian artists visualize a creature of fire and wind that can also talk to and interact with people? Rather than try to represent this visual paradox, the painters of the Catacombs portrayed angels simply as men, a logical solution as this was a term by which they are called again and again in both Old Testament and New. Among the earliest surviving representations of angels in the Catacombs are the Annunciation (e.g. Catacomb of Priscilla, fig. 1), in which the angel Gabriel tells Mary that she is to be the mother of Christ, and scenes from the story of Abraham (e.g. Via Latina Catacomb, fig. 2), in which Abraham is visited by three angels who announce that he will be the father of a great nation.

Fourth-century sarcophagi are another site that includes early portrayals of Christian angels. There angels are again represented as men in the Sacrifice of Abraham (fig. 3), in which an angel stops Abraham from sacrificing his son, and in the Three Hebrews in the Fiery Furnace (fig. 4), where an angel prevents the fire from harming the youths. 10 So close visually are these fourth-century angels to men that several of them sport beards (see fig. 4) and at least one is balding (see fig. 3). This gives them a solid physical presence as they interact with people. It even seems to indicate a sort of aging process for angels. Into the fourth century, angels continue to have a human and male appearance. Wings, which would soon become the most essential visual aspect of an angel, had not yet put in an appearance.

Bearded angels make no further appearance in art after the fourth century. The general disappearance of beards coincides in the fourth century with the appearance of wings, both resulting from the same impetus, as I will argue below. The one surviving exception is an angel with a beard on an early fifth-century Italian ivory carving of the Baptism of Christ (fig. 5). In this scene, the angel is not only bearded, but also winged. No other angel with both a beard and wings is known, and no other angel wears a beard after the close of the fourth century. The change is a dramatic one from angels that are visually undistinguished from men to the winged beings we still recognize today. By the mid-fifth century, winged angels had taken over and become the norm in Christian art. 11

10 For Early Christian sarcophagi, see Johann Wilpert, I sarcophagi cristiani antichi, Rome, 2 vols., 1929.

11 Periodically through the centuries, Christian angels have been represented without wings, but after the fitth century these became the exception rather than the rule. 
The shift to winged angels took place during the fourth century, a time that saw first the legalization of Christianity and then the conversion of the Roman Empire to this relatively young religion. As the Christian community grew in sophistication, so did its art. By the late fourth century, it no longer sufficed to represent angels, who held a position somewhere between God and people, simply as men. Between God and man is the sky, a conceptual place where divinity had always been localized, a physical place occupied exclusively by winged creatures. How else but by flying with wings could an angel carry a message from God down to earth? The concept of Christian angels as winged beings had existed from at least the beginning of the third century when Tertullian (c.160-c.240) said, "Every spirit is winged, both angels and demons. In this way, in a moment they are everywhere: all the world is for them one place; what is taking place everywhere is as easy for them to know as to tell. It is thought that their velocity is divine because their substance is not known».12 Wings represented the speed with which angels traverse the heavens, a speed unimaginable to earthbound man. In the invention of the winged angel, there may have been some conflation of the dove of the Holy Spirit and the angel as a flying spiritual messenger. Just as the dove of Genesis served as a messenger to Noah, telling him with an olive branch that the waters of the flood were receding (Gen. 8:811), the dove of the Holy Spirit was present at the baptism of Christ, when God announced, "This is my Son, the Beloved; my favor rests on him." (Matt. 3:17) ${ }^{13}$ The dove-angel conflation can be seen in the Catacomb of Priscilla, which has a most unusual representation of the Three Hebrews in the Fiery Furnace (fig. 6). Rather than a man, with or without wings, the protecting angel is here portrayed as the dove itself.

The nature of angels and the meaning of their wings was a subject of debate in the fourth century. John Chrysostom (340/50-407) wrote, "What do the powers reveal to us by these wings: The exaltedness and ethereality and lightness and speed of their nature. For which reason, Gabriel descends fleet; not that the wings are part of the bodiless power, but that he descends from realms on high and returns to his abode whence he was sent.»14 $\mathrm{He}$ thus explains that wings are an essential aspect of angel as messenger without being a part of an angel's true, immaterial nature. Wings also enable the angel to descend, to lower himself in order to interact with man. Yet John Chrysostom's phrase

12 Patrologia cursus completus, Series latina, Ed. J.P. Migne, 221 vols. in 222 pts., Paris, 1844-80, 1:407A-408A.

13 See also Mark 1:9-11 and Luke 3:21-22, in which the voice of God addresses Jesus directly.

14 Patrologia cursus completus, Series graeca, ed. J.-P. Migne, 161 vols. in 166 pts, 1857-66, 56:137. 
«bodiless power» and Tertullian's statement that "their substance is not known" indicate an uncomfortable ignorance on man's part. The angel's essence is not known, not understood. Angels are believed to be fire, breath, spirit, and radiance, immaterial yet present in the material world. Angels are by their very nature ambiguous, incomprehensible. Perhaps they are not described in the canonical books of the Bible because they cannot be truly described. Their nature cannot be understood, and therefore the first angels could not be represented as other than man.

Angels seem to be above people, both literally and in the hierarchy of creation. But they are also below Christ. Paul's Letter to the Hebrews makes clear the distinction between Christ and the angels.

[Christ] is the radiant light of God's glory and the perfect copy of his nature, sustaining the universe by his powerful command; and now that he has destroyed the defilement of sin, he has gone to take his place in heaven at the right hand of divine Majesty. So he is now as far above the angels as the title which he has inherited is higher than their own name. God has never said to any angel: You are my Son, today I have become your father; or: I will be a father to him and he a son to me. Again, when he brings the First-born into the world, he says: Let all the angels of God worship him. About the angels, he says: He makes his angels winds and his servants flames of fire, but to his Son he says: God, your throne shall last for ever and ever; ... God has never said to any angel: Sit at my right hand and I will make your enemies a footstool for you. The truth is they are all spirits whose work is service, sent to help those who will be the heirs of salvation. (Heb. 1:2-14)

Since ali the children share the same blood and flesh, [Christ] too shared equally in it, so that by his death he could take away all the power of the devil, who had power over death, and set free all those who had been held in slavery all their lives by the fear of death. For it was not the angels that he took to himself; he took to himself descent from Abraham. It was essential that he should in this way become completely like his brothers. (Heb. 2:14-17)

Because Christ chose to become a man, he gave humanity a rank above the angels, despite the paradox of the heavenly nature of angels and the earthly nature of men. He raised people up so that they held a position second only to God. The angels were merely God's messengers; people were his children. Yet this distinction was not clear in the representations of angels in which Christ, men, and angels were visually identical.

Although the superiority of Christ to the angels was clear during the time of Paul, some of the Church fathers wrote of Christ as though he himself

15 Justin, Dialtyphro 61.1; as quoted by Charles Arthur Giesechen, "Angelomorphic Christology: Antecedents and Early Evidence," Ph.D. dissertation, University of Michigan, 1995, 16 Tertullian, De carne Cristi 14; Geischen, 214. 
were a spirit or an angel. Justin (c.100-c.165) names Angel as one of the titles of Christ. «God has begotten of Himself a certain rational Power as a Beginning before all other creatures. The Holy Spirit indicates this Power by various titles, sometimes the Glory of the Lord, at other times Son, or Wisdom, or Angel, or God, or Lord, or Word.»15 Tertullian, however, explained that while Christ may be called Angel, he is not, in fact, an angel. "He [Christ] is indeed called "Angel of Great Counsel," that is, messenger, by a word that refers to office rather than nature. For he had as his mission to announce to the world the great purpose of the Father, namely that concerning the restitution of humanity. $\mathrm{He}$ is not, however, on this account to be understood as an actual angel like Gabriel or Michael.»16 Yet by the time of Novatian (c.250 AD), Christ was understood to be Angel in nature as well as in office, whereas God the Father was simply God. In this way, Christ could become visible to humanity, but God could not. This argument explained how it could be that some Old Testament figures came face to face with God and lived to tell about it, when it was written in Exodus 33:20, "Man shall not see me and live." Novatian wrote:

Moreover it is written simply in the place of God, for it is not said in the place of the angel and God, but only of God; and He who promises those things is manifested to be both God and Angel, so that reasonably there must be a distinction between Him who is called God only, and Him who is declared to be not God simply, but Angel also. Whence if so great an authority cannot here be regarded as belonging to any other angel, that $\mathrm{He}$ should also avow Himself to be God, and should bear witness that a vow was made to Him, except to Christ alone, to whom not as angel only, but as to God, a vow can be vowed; it is manifest that it not be received as the Father, but as the Son, God and Angel. Moreover, if this is Christ, as it is, he is in terrible risk who says that Christ is either man or angel alone, withholding from him the power of the Divine name,-an authority which he has constantly received on the faith of the heavenly Scriptures, which continually say that $\mathrm{He}$ is both Angel and God. 17

One of the consequences of naming Christ an angel was that the position of angels was thereby exalted. The words of Paul were forgotten: "The truth is [angels] are all spirits whose work is service, sent to help those who will be the heirs of salvation.» Angels were increasingly the object of worship by those who should have recognized in themselves "the heirs of salvation," but instead subordinated themselves to angels. Angel worship became such a serious problem that it was prohibited at the Council of Laodicea (343-381). 18 There it was stated, "Christians must not abandon

17 Novatian, De Trinitate 19; Geischen, 218.

18 The dates for this council are uncertain. It was held some time between 343 and 381 , the dates of two well-established councils. For the Council of Laodicea, see Charles Joseph Hefele, Histoire des Conciles d'après les documents originaux. Vol. 1, part 2, 1907, 989-1028. 
the Church of God and turn themselves away and venerate the angels and introduce a cult of angels. That is forbidden. He who is found guilty of that dissembling idolatry will be excommunicated, because he has forgotten our lord Jesus Christ, the son of God, and he has gone to idolatry.» 19

In the fourth century, therefore, it became necessary to demonstrate visually that angels are not worthy of worship, and that they are different both from man and from Christ who had been a man. When people worshipped angels, they forgot that, because of Christ, angels are above yet below man. Christ lived as a man and took the form of a man, so angels had to be represented with some other form. Wings were a way to set angels apart from humanity while retaining other aspects of angelic nature, such as angel as fleet messenger. Wings simultaneously represent the heavens and a tie to earth, for even birds, winged creatures, must eventually return to earth. Wings are the link that connects angels with the heavens, but wings also tie angels to animals; they serve to remind the viewer that angels are creatures, beneath humanity despite belonging to the heavens.

The statutes of the Council of Laodicea reflect the concerns of Christian leaders in the mid fourth century, concerns that are made visible in the contemporaneous creation of images of winged angels. 20 Angels were not to be worshipped, so a new manner of representing them had to be created. The paradoxical nature of angels is made clear in works of art, which can portray what could not otherwise be seen. Paintings and sculpture show the truth of angels, despite their invisibility. Artists incorporate the irrational with the logical, using wings to express the anomalous position of angels, and thus to remind the viewer of their complicated character in a way that a simple anthropomorphic angel could never do.

Beyond the interest in angels, the Council of Laodicea was greatly concerned with hierarchy, both within the church and as the church interacted with its Christian and non-Christian neighbors. Although the traditional location of the church had been in private homes for the first three centuries of Christianity, the Council now localized religion in the public space, stating, «Bishops and priests should not offer the sacrifice in houses.»21 It specified the acts sub-deacons, deacons, priests and bishops may do in the presence of each other, and in certain places, and

19 Hefele, 1017.

20 Despite official sanction, the cult of angels continued to thrive and was finally reinstated in 787 at the Seventh Ecumenical Synod.

21 Hefele, 1025. 
at certain times, stating also that they could not be magicians. It was greatly concerned with relationships between men and women, and between Christians and non-Christians. Second marriages, for example, should not be done secretly, and one could not marry either oneself or one's children to heretics unless they promised to become Christians. Decorum must be maintained so "that Christians who attend weddings should not jump or dance, but attend the meal with decency, as becomes Christians".22 Women were to be kept separate from church doings. They were not to approach the altar, and «the people of the church, clerics or ascetics, shall not bathe in one and the same bath with women, because this is the greatest reproach of the pagans".23 As for the separation of religions, Christians were not to "Judaise» by refraining from working on Saturday, nor could they attend services in cemeteries of heretics, nor pray with heretics, nor attend feasts or sacrifices of Jews or pagans.

A need to organize into hierarchies and to clarify positions both within and without the Christian community is clear from the Council of Laodicea. The image of the winged angel in art seems to have received its creative impetus from this late fourth-century need. A factor in the development of winged angels and the comprehension of their paradoxical nature may have been the attitude toward women evinced by the Council of Laodicea. Women were to be kept separate from things and people of the church, presumably because of their corrupting influence. This would appear to have included angels. Macarius Magnes (fourth century) recommended that one of the ways for men to imitate angels is to avoid marrying women.

So that if someone should hear that in heaven [angels] have a spiritual nature, rejoicing in the grace of immortality, toward imitation of these he accommodates his life, and models himself after their worth in his deeds, and avoiding marriage and fleeing the symbols of corruption, and in the end coming to the passage of death, into the court of the blessed, and of the angels, he should come lifted up. 24

Yet not even angels were completely safe from the dangers posed by women. The negative influence that women could wield over angels was well known from Genesis and the Second Book of Enoch in which angels gave up their place in heaven in order to marry daughters of men. Thus a further reason for the change from anthropomorphic angels to winged angels may be that angels as men were too attractive to women-and too susceptible to their female charms. Angels from the late fourth century,

22 Hefele, 1023.

23 Hefele, 1016.

24 C. Blondel, Macarii Magnetis quae supersunt ex inedito codice, Paris, 1876, Caput XXVII, 'Solutio de Angelis immortalibus et de Tabulis digito Dei scriptis,' $214,10-20$. 
therefore, were conceived of as less male and more spiritual in nature, never again to be seen with a beard.

In light of the attitude toward women, it would seem curious that the earliest Christian angels with wings are modeled on pagan female personifications, such as Nike (fig. 7). Only subtle differences of drapery distinguish the portrayals of Victories and winged angels: Victory wears a peplum and sometimes exposes a leg or a breast (fig. 8), while an angel is always fully covered by a toga (fig. 9). These beings, however add function in different ways. Victory, as her name suggests, celebrates a moment of triumph, thus her position on Constantine's arch (fig. 10), and on sarcophagi (fig. 11), suggesting the Christian victory over death. The angel, by contrast, is multitalented: he can bring harbingers of doom or delight, he can protect or punish. Both beings interact with humanity only at moments of epiphany, changing thereafter the course of history.

If the quest had been for a winged male model, it could logically have led the Christian iconographers to Mercury, winged messenger of the gods. But with the problem of angel worship already a serious concern, artists had to be sure that their angels would not be mistaken for pagan gods. The use, without exception, of masculine nouns and the old stories of angels dallying with women determined that visually, if not physically as well, angels are men. By using female models, particularly personifications of Victory, late fourth-century artists deliberately added another layer of ambiguity to their images. Their audience would surely recognize in winged male angels the visual reference to female prototypes, giving further evidence of the paradoxical nature of angels. A female model for a male figure gave winged angels a gender-neutrality that anthropomorphized angels had not had. Although angels were referred to as men in both Testaments, Jesus had indicated that angels were neither male nor female when he answered the Sadducees' question, «If I have been married seven times, which one of the women will be my wife in heaven?" Jesus replied, «At the resurrection men and women do not marry; no, they are like the angels in heaven." (Luke 20:27-36)

Thus the image of the winged angel manages to combine a female model with a male nominative ("angelos") in order to portray a creature that is spirit, not belonging to either gender. The visual form of a man with wings satisfied the perceived need in the fourth century for an angel that was neither man nor woman, neither man nor God. The winged image was a successful visual metaphor that managed to capture all the ambiguities inherent in the angelic nature and explain them in a way that has remained clearly convincing to the present day. 


\section{BIBLIOGRAPHY}

Berefelt, Gunnar, A Study on the Winged Angel: The Origin of a Motif, Stockholm, 1968.

BERGER, KARL F.J. "Das Heilige Antlitz III Engel.»Zeitschrift für ostkirchliche Kunst Hermeneia vol. 5, no. 4 (1989): 206-211.

"Engelflügel: eine Betrachtung für Ikonmaler." Zeitschrift für ostkirchliche Kunst Hermeneia vol. 7, no. 1 (1991): 19-22.

BLONOEL, C., Macarii Magnetis quae supersunt ex inedito codice, Paris, 1876, Caput XXVII, 'Solutio de Angelis immortalibus et de Tabulis digito Dei scriptis,' 214, 10-20.

BUSSAGLI, MARCO, "Angelo," Enciclopedia dell'arte medievale, Rome, 1991-, 1:629-38.

"Gli angeli e i venti: considerazioni sul simbolismo aereo delle ali angeliche," Atte medievalia 5/2 (1991): 107-26.

Storia degli angeli. Racconto di immagini e di idee, Milan, 1991.

CABrol, Fernand, «Anges," Dictionnaire d'archéologie chrétienne et de liturgie, Paris, 1907, vol. 1 part 2, cols. 2080-2161.

CACCIARI, MASSIMO, The Necessary Angel, Albany, 1994 (French edition, 1988).

"Engel," Reallexikon für Antike und Christentum, Stuttgart, 1962, vol. 5, cols. 53-322.

Charles, R.H., ed., The Apocrypha and Pseudepigrapha of the Old Testament, Oxford, 1913, 2 vols.

FITZMYER, JOSEPH A., "A Feature of Qumran Angelology and the Angels of 1 Cor. 11:10," Paul and Qumran: Studies in New Testament Exegesis, ed. Jerome Murphy-O'Connor, Chicago, 1968, 31-47.

Gieschen, Charles ARthur, "Angelomurphic Christology: Antecedents and Early Evidence," Ph.D. dissertation, University of Michigan, 1995

Hefele, Charles Joseph, Histoire des Conciles d'après les documents originaux. Vol. 1, part 2, 1907, 989-1028. Jerusalem Bible, New York, 1966.

Kirschbaum, Engelbert, "Engel," Lexikon der christlichen Ikonographie, Herder, 1968, vol. 1, cols. 626-642.

LUNOBERG, MABEL, Studier i änglabildens utformning och funktion under den kristna kyrkans första årtusende, Uppsala, 1981.

MaRShaLl, GeORge J., Angels: An Indexed and Partially Annotated Bibliography of Over 4300 Scholarly Books and ARticles Since the 7th Century B.C., Jefferson, North Carolina, 1999.

Nicolai, Vincenzo FIOCHI, Fabaizio Bisconti and Danilo Mazzoloni, Le Catecombe Cristiaria di Roma, Regensburg, 1998.

Patrologia cursus completus, Series graeca, ed. J.-P. Migne, 161 vols, in 166 pts. 1857-66.

Patrologia cursus completus, Series latina, Ed. J.-P. Migne, 221 vols. in 222 pts. Paris, 1844-80.

PeERs, Glenn Alan, "Representing Angels: Cult and Theology in Byzantine Art," Ph.D. dissertation, Johns Hopkins University, 1995.

Subtle Bodies: Representing Angels in Byzantium, Berkeley, 2001.

Petzold, ANDREAS, "'His Face Like Lightning': Colour as Signifier in Representations of the Holy Women at the Tomb," Arte Medievale vol.6, no. 2 (1992): 149-155.

ROFÉ, Alexander, The Belief in Angels in the Bible and in Early Israel, Jerusalem, 1979.

SCHnEIDER, Bernard N., The World of Unseen Spirits: A Study Guide, Winona Lake, Indiana, 1975.

Stuhlfauth, G., Die Engel in der altchristlichen Kunst, Freiburg, 1897.

VILlette, JeAnNe, L'Ange dans l'art d'occident, Paris, 1940.

WERNER, M., "On the Origin of Zoanthropomorphic Evangelist Symbols: The Early Christian

Background," Studies in /conography 13 (1984/6): 1-35.

WILPERT, JOHANN, I sarcophagi cristiani antichi, Rome, 2 vols., 1929. 
Fig. 3

Sarcophagus, fourth century, Lateran Museum, Rome. (Marco Bussagli, Storia degli angeli, racconto di immagini e di idee, Milan, 1991, 59.)
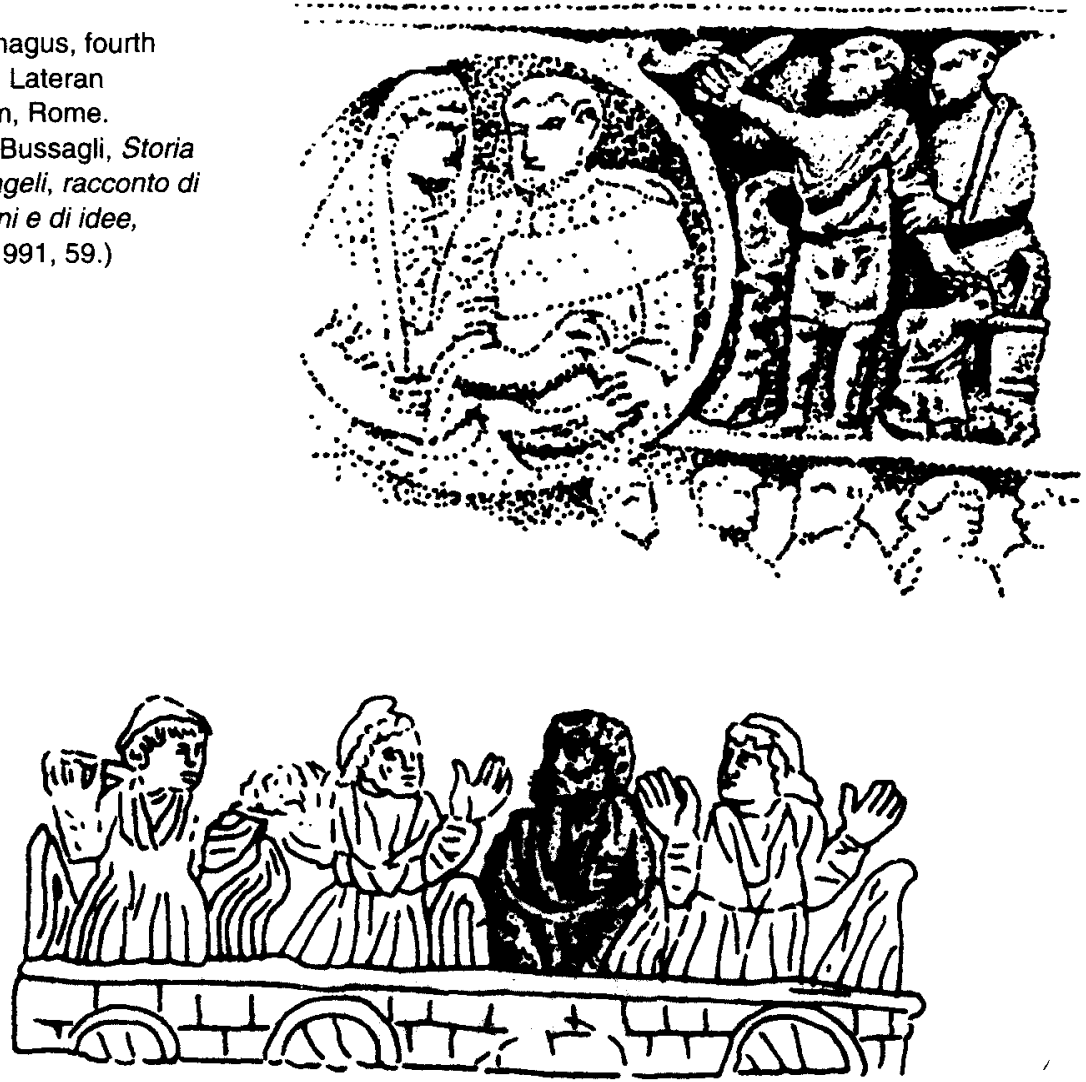

Fig. 4 Sarcophagus, fourth century, Capitoline Museum, Rome. (Marco Bussagli, Storia degli angeli, racconto di immagini e di idee, Milan, 1991, 55.)

Fig. 5

Ivory, c. 400 , British Museum, London. (Mabel Lundberg,

Studier $i$ änglabildens utformning och funktion under den kristna kyrkans första årtusende, Uppsala, 1981, 81.)

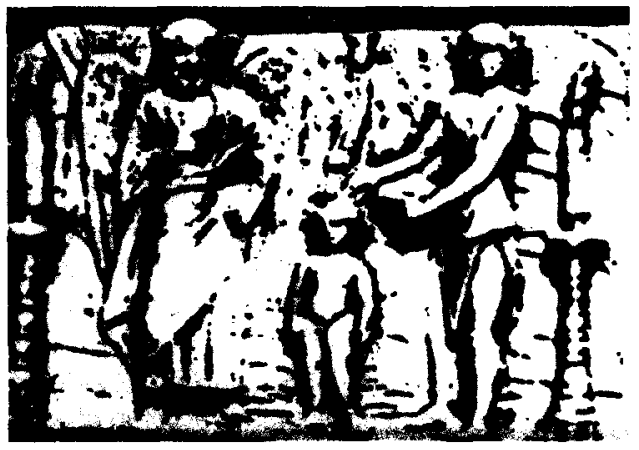




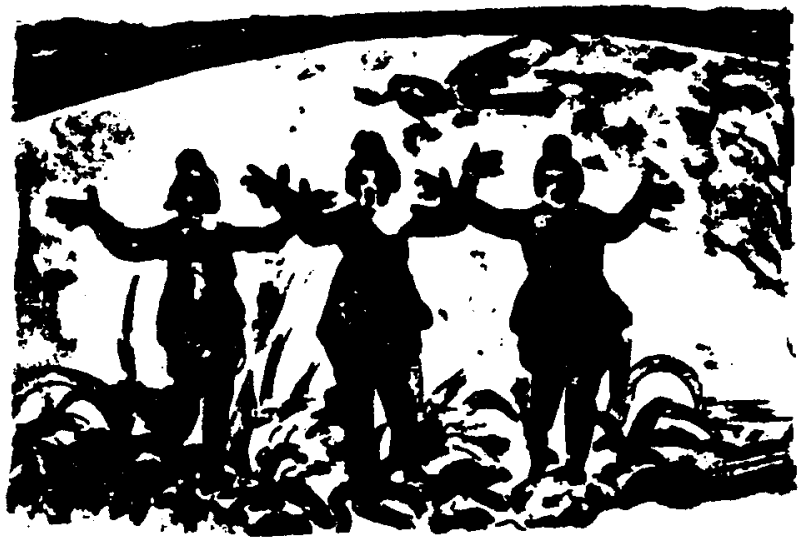

Fig. 6 Catacomb of Priscilla, second half of third century, Rome. (Mabel Lundberg, Studier i änglabildens utformning och funktion under den kristna kyrkans första ártusende, Uppsala, 1981, 47.)

Fig. 7

Stucco relief, first century, Museo

Nazionale, Rome.

(Gunnar Berefelt, $\boldsymbol{A}$ Study on the Winged Angel: The Origin of a Motif, Stockholm, 1968,

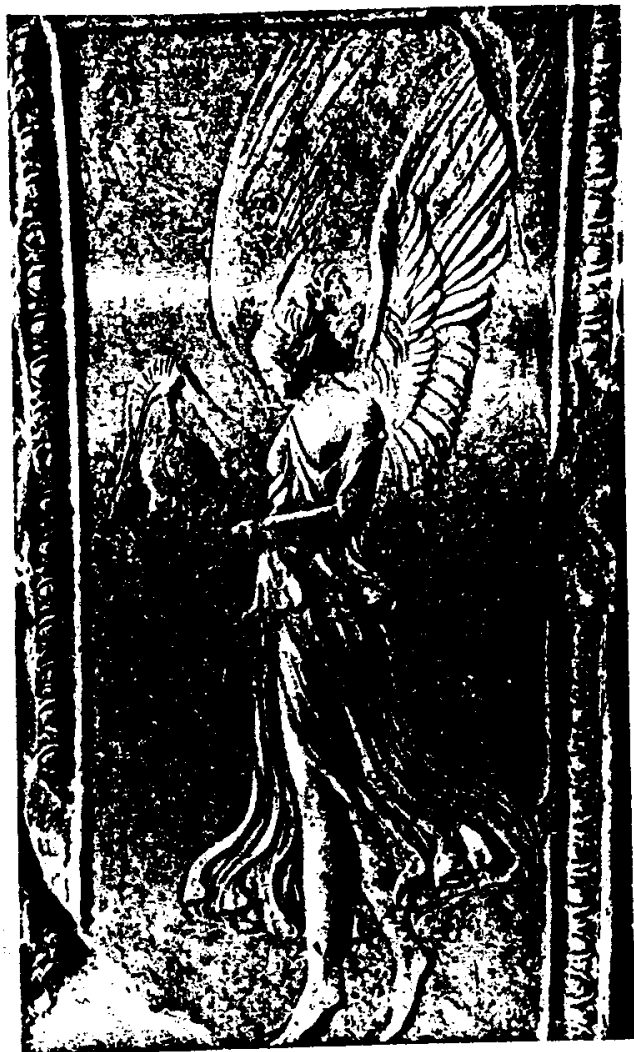




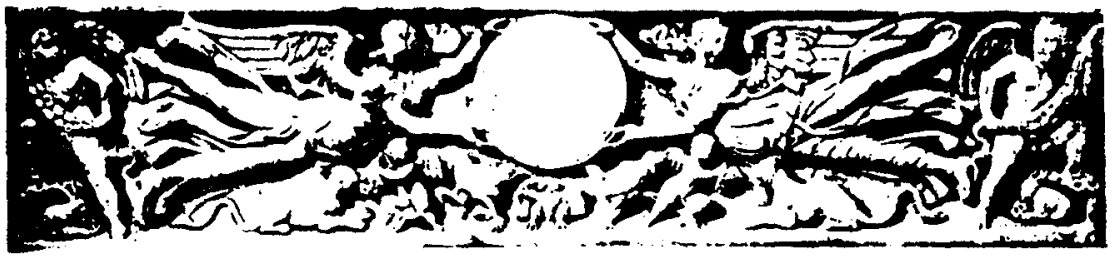

Fig. 8 Sarcophagus, third century, Palazzo dei Conservatori, Rome.

(Gunnar Berefelt, A Study on the Winged Angel: The Origin of a Motif, Stockholm, 1968, 30)

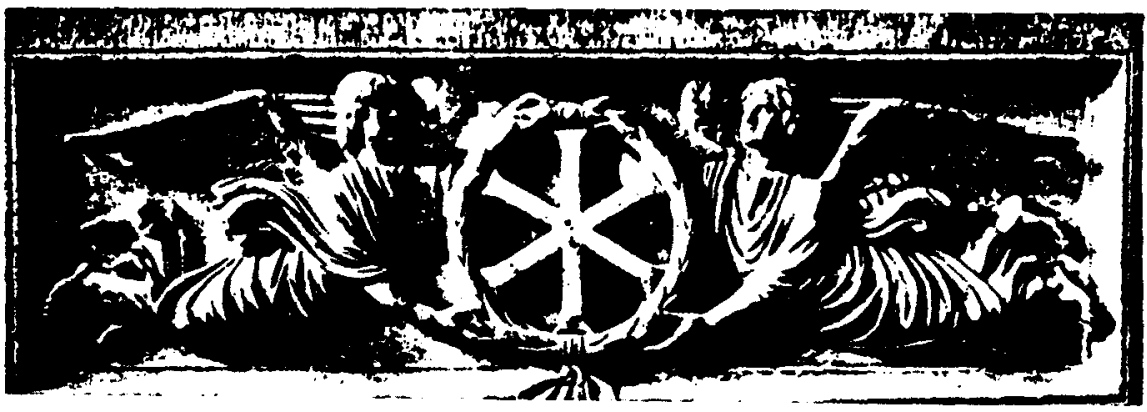

Fig. 9 Sarcophagus, second half of fourth century, Ottoman Museum, Istanbul

(Gunnar Berefelt, A Study on the Winged Angel: The Origin of a Motif, Stockholm, 1968, 8)

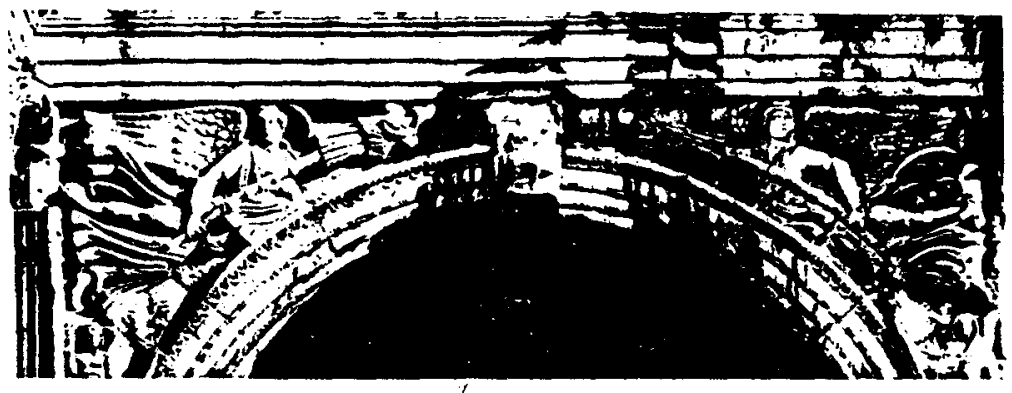

Fig. 10 Arch of Constantine, 313-315, Rome

(Gunnar Berefelt, A Study on the Winged Angel: The Origin of a Motif, Stockholm, 1968, 73) 


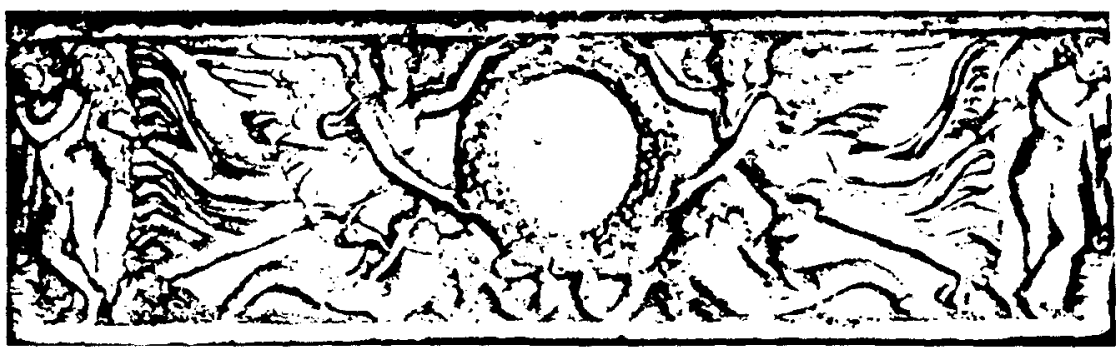

Fig. 11 Sarcophagus, third century, Museo Nazionale, Rome

(Gunnar Berefelt, A Study on the Winged Angel: The Origin of a Motif, Stockholm, 1968, 73) 
